\title{
Clinical and pathological investigation of adnexal masses in adolescents who underwent surgery in a tertiary center
}

\author{
Tersiyer bir merkezde ameliyat olan adölesanlardaki adneksiyel kitlelerin klinik ve patolojik \\ incelenmesi
}

Hediye Dağdeviren, Hüseyin Cengiz, Ammar Kanawati, Sema Süzen Çaypınar, Murat Ekin

\begin{abstract}
Objective: Adnexal masses are the most common reason for gynecologic surgery in adolescent patients. Early detection and adequate management of adnexal lesions are very important for saving lives and preserving fertility. In this study, we analyzed the clinical characteristics of 106 Turkish adolescent women who underwent surgery for adnexal masses.
\end{abstract}

Methods: The study included 106 patients aged $\leq 20$ years that underwent surgery for adnexal masses at our hospital between January 2008 and December 2013. Clinical profiles were retrospectively collected from the hospital medical records. The records were analyzed for demographic profiles, initial symptoms, preoperative radiologic findings, operative approach, surgical procedure, pathology findings, and the maximum diameter of the adnexal mass.

Results: The age of the patients ranged from 12 to 20 years (median, 18.8 years). The most common initial symptom in these patients was abdominal pain (56.6\%). Non-neoplastic ovarian lesions in the patients included $7(6.6 \%)$ corpora hemorrhagica, $10(9.4 \%)$ corpus luteal cysts, $4(3.8 \%)$ paratubal cysts, and $7(6.6 \%)$ simple cysts. Benign neoplastic tumors included 20 (18.9\%) mature cystic teratomas (i.e., dermoid tumors), 10 (9.4\%) serous cystadenomas, $1(0.9 \%)$ mucinous cystadenomas, and $7(6.6 \%)$ endometriomas. The most common surgical approach and procedure were laparoscopy (67.0\%) and cystectomy $(60.4 \%)$, respectively.

Conclusion: Laparoscopy can be performed in many adolescent patients and conservative, adnexal-sparing surgery should be encouraged for all patients. Ovarianpreserving techniques should be a priority when surgery is performed for benign masses in order to optimize future fertility potential. J Clin Exp Invest 2015; 6 (2): 96-101

Key words: Adolescent, adnexal, laparoscopy

\section{ÖZET}

Amaç: Adneksiyel kitleler adölesan hastalarda jinekolojik cerrahinin en sık nedenidir. Erken tanı ve yeterli tedavi fertilitenin korunmasında ve yaşamın devamında çok önemlidir. Bu çalışmada hastanemizde adneksiyel kitle nedeniyle ameliyat edilen 106 hastanın klinik özelliklerini inceledik.

Yöntemler: Çalışma Ocak 2008 ve Aralık 2013 yılları arasında adneksiyel kitle nedeniyle ameliyat edilen 20 yaş altı 106 hastayı içermektedir. Hastaların klinik özellikleri geriye dönük olarak hastane kayıtlarından elde edildi. Kayıtlardan hastaların demografik özellikleri, başvuru şikayetleri, ameliyat öncesi radyolojik bulguları, operasyon şekli, patolojik bulguları ve kitlenin maksimum çapı elde edildi.

Bulgular: Hastaların yaşları 12 ile 20 arasında değişmekteydi. (ort, 18,8). Hastaların en sık başvuru semptomu karın ağrısı idi $(\% 56,6)$. Benign ovaryan lezyonlar yönünden incelediğimizde hastaların 7 tanesinde $(\% 6,6)$ korpus hemorajikum, 10 tanesinde $(\% 9,4)$ korpus luteum, 4 tanesinde $(\% 3,8)$ paratubal kist ve 7 tanesinde $(\% 6,6)$ basit kist vardı. Benign neoplastik lezyonlardan hastaların 20 tanesinde $(\% 18,9)$ matur kistik teratom (dermoid tümör), 10 tanesinde $(\% 9,4)$ seröz kistadenom, 1 tanesinde $(\% 0,9)$ müsinöz kistadenom ve 7 tanesinde $(\% 6,6)$ endometrioma vardı. En sık cerrahi yaklaşım laparoskopi $(\% 67,0)$ ve en sık uygulanan ameliyat kistektomiydi. $(\% 60,4)$.

Sonuç: Laparoskopi ve fertilite koruyucu cerrahi adölesan yaşta bütün hastalarda ilk tercih edilen yöntem olmalıdır. Cerrahi yapılan ve benign kitlesi olan hastalarda gelecekteki fertiliteyi korumak için over koruyucu cerrahi teknikler uygulanmalıdır.

Anahtar kelimeler: Adölesan, adneksiyel, laparoskopi 


\section{INTRODUCTION}

Adnexal masses are the most common reason for gynecologic surgery in adolescent patients. Early detection and adequate management of adnexal lesions are very important for saving lives and preserving fertility. The incidence of gynecologic surgical procedures in adolescent patients is low, but these procedures are not very rare [1]. Several studies regarding the clinical characteristics of adnexal masses in adolescents have been conducted [2-9]. In these cases, the diagnosis of adnexal masses was difficult and also delayed or missed owing to the low index of suspicion and nonspecific complaints. It is necessary to obtain more information about the clinical characteristics of adolescents with adnexal masses to facilitate early diagnoses and provide adequate management for those patients.

In this study, we analyzed the clinical characteristics of 106 Turkish adolescent women who underwent surgery for adnexal masses, performed by gynecologists at a tertiary center, during the last 5 years.

\section{METHODS}

The study included 106 patients aged $\leq 20$ years who underwent surgery for adnexal masses at tertiary center between January 2008 and December 2013. Clinical profiles were retrospectively collected from the hospital medical records. The records were analyzed for demographic profiles, initial symptoms, preoperative radiologic findings, operative approach, surgical procedure, pathology findings, and the maximum diameter of the adnexal mass (obtained from the pathology report or as described by the operating surgeon if the mass was decompressed intra-operatively). The surgical procedures performed were categorized as cystectomy, detorsion, primary repair of the ovary, salpingectomy, unilateral salpingo-oophorectomy, oophorectomy, aspiration of cyst, abscess drainage, peritoneal biopsy, adhesiolysis, and salpingostomy. Malignant lesions were defined as epithelial, germ cell, sex cord stromal, and metastatic. Benign masses were defined as functional cysts, cyst adenomas, mature teratomas, endometriomas, and paratubal cysts.

Statistical analyses were performed using the SPSS software (SPSS Inc., Chicago, IL, USA). For descriptive data, the mean, standard deviation, median, minimum-maximum, rate, and frequency values were used.

\section{RESULTS}

During the study period, 106 patients underwent surgery for adnexal masses. The age of the patients ranged from 12 to 20 years (median, 18.8 years). All patients were postmenarcheal and $35.8 \%$ of patients have had sexual intercourse. The most common initial symptom in these patients was abdominal pain $(56.6 \%)$. Other initial symptoms were groin pain $(32.1 \%)$, nausea and vomiting $(4.7 \%)$, vaginal bleeding $(0.9 \%) ; 5.7 \%$ of patients had no symptoms. The mean body mass index (BMI) in the identified group was 23.2 (range, 15.6-45.4). Adnexal lesions were right sided $(55.7 \%)$, left sided $(36.8 \%)$, or bilateral $(7.5 \%)$. The sociodemographic and clinical characteristic of patients are shown in Table 1.

Table 1. Sociodemographic and clinical characteristic of patients

\begin{tabular}{llcc}
\hline & \multicolumn{1}{c}{ Min - Max } & \multicolumn{2}{c}{ Mean \pm SD } \\
\hline Age (years) & $12-20$ & \multicolumn{1}{c}{$18.8 \pm 1.8$} \\
Parity & $0-2$ & \multicolumn{2}{c}{$0.2 \pm 0.4$} \\
BMI $\left(\mathrm{kg} / \mathrm{m}^{2}\right)$ & $15.6-45.4$ & $23.2 \pm 5.1$ \\
\hline & & $\mathbf{n}$ & $\%$ \\
\hline Sexual & Yes & 38 & 35.8 \\
intercourse & No & 68 & 64.2 \\
& Abdominal pain & 60 & 56.6 \\
& Groin pain & 34 & 32.1 \\
Complain & Nausea / vomiting & 5 & 4.7 \\
& Vaginal bleeding & 1 & 0.9 \\
& None & 6 & 5.7 \\
& Cesarean section & 3 & 2.8 \\
History of & Appendectomy & 6 & 5.7 \\
operation & Cystectomy & 1 & 0.9 \\
& Salpingectomy & 1 & 0.9 \\
& None & 95 & 89.6 \\
& Right & 59 & 55.7 \\
Side & Left & 39 & 36.8 \\
& Bilateral & 8 & 7.5 \\
\hline
\end{tabular}

BMI; Body Mass Index, SD: Standard deviation

Many patients underwent more than one diagnostic test owing to the varied nature of presented symptoms; however, pelvic ultrasound was most commonly performed. The preoperative radiologic reports were available for all patients and included findings from 90 ultrasonographic, 4 computed tomographic, and 12 magnetic resonance images. The mean mass size of the ovarian cysts ranged $1.5-20 \mathrm{~cm}$. Eighty one $(76.4 \%)$ emergency surger- 
ies were performed because of acute abdominal pain (Table 2).

Table 2. Preoperative clinical and diagnostic characteristic of patients

\begin{tabular}{llcc}
\hline & & Min-Max & Mean \pm SD \\
\hline \multicolumn{2}{l}{ Mass diameter $(\mathbf{c m})$} & $\mathbf{1 . 5 - 2 0}$ & $\mathbf{6 . 3 6 \pm 3 . 1}$ \\
\hline \multirow{2}{*}{ Operation } & Emergency & $\mathbf{n}$ & $\mathbf{\%}$ \\
method & Elective & 25 & 76.4 \\
& Ultrasonography & 90 & 23.6 \\
Diagnostic & Computed tomography & 4 & 3.8 \\
procedure & Magnetic resonance & 12 & 11.3 \\
&
\end{tabular}

SD: Standard deviation

Table 3. Operative and pathological characteristic of patients

\begin{tabular}{|c|c|c|c|}
\hline & & $\mathbf{n}$ & $\%$ \\
\hline \multirow{3}{*}{ Surgical approach } & Laparascopy & 71 & 67.0 \\
\hline & Laparatomy & 30 & 28.3 \\
\hline & $\begin{array}{l}\text { Laparoscopy after } \\
\text { laparatomy }\end{array}$ & 5 & 4.7 \\
\hline \multicolumn{4}{|l|}{ Pathology } \\
\hline \multirow{5}{*}{ Non-neoplastic } & Corpus luteum & 10 & 9.4 \\
\hline & Simple cyst & 7 & 6.6 \\
\hline & Paratubal cyst & 4 & 3.8 \\
\hline & Corpus hemorrhagicum & 7 & 6.6 \\
\hline & Endometrioma & 7 & 6.6 \\
\hline \multirow{3}{*}{ Benign neoplastic } & Dermoid & 20 & 18.9 \\
\hline & Serous cystadenoma & 10 & 9.4 \\
\hline & Mucinous cystadenoma & 1 & 0.9 \\
\hline \multirow[t]{2}{*}{ Malignant tumors } & $\begin{array}{l}\text { Serous papillary } \\
\text { adenocarcinoma }\end{array}$ & 1 & 0.9 \\
\hline & Tubal necrosis & 2 & 1.9 \\
\hline \multirow[t]{3}{*}{ Torsion } & $\begin{array}{l}\text { Necrosed and } \\
\text { torsioned ovary }\end{array}$ & 5 & 4.7 \\
\hline & Abscess & 2 & 1.9 \\
\hline & Tuberculosis & 1 & 0.9 \\
\hline \multirow[t]{3}{*}{ Others } & Cyst hydatid & 1 & 0.9 \\
\hline & Ectopic pregnancy & 10 & 9.4 \\
\hline & None & 18 & 17 \\
\hline \multicolumn{4}{|l|}{ Surgical procedure } \\
\hline \multicolumn{2}{|l|}{ Cystectomy } & 64 & 60.4 \\
\hline \multicolumn{2}{|l|}{ Detorsion } & 32 & 30.2 \\
\hline \multicolumn{2}{|l|}{ Primary repair } & 5 & 4.7 \\
\hline \multicolumn{2}{|l|}{ Salpingectomy } & 11 & 10.4 \\
\hline \multicolumn{2}{|c|}{ Unilateral salpingo-oophorectomy } & 8 & 7.5 \\
\hline \multicolumn{2}{|l|}{ Aspiration of cyst } & 2 & 1.9 \\
\hline \multicolumn{2}{|l|}{ Abscess drainage } & 2 & 1.9 \\
\hline \multicolumn{2}{|l|}{ Peritoneal biopsy } & 2 & 1.9 \\
\hline \multicolumn{2}{|l|}{ Adhesiolysis } & 2 & 1.8 \\
\hline \multicolumn{2}{|l|}{ Salpingostomy } & 2 & 1.9 \\
\hline
\end{tabular}

Non-neoplastic ovarian lesions in the patients included 7 (6.6\%) corpora hemorrhagica, $10(9.4 \%)$ corpus luteal cysts, $4(3.8 \%)$ paratubal cysts, and $7(6.6 \%)$ simple cysts. Benign neoplastic tumors included $20(18.9 \%)$ mature cystic teratomas (i.e., dermoid tumors), 10 (9.4\%) serous cystadenomas, $1(0.9 \%)$ mucinous cystadenomas, and 7 (6.6\%) endometriomas. Only 1 patient had a malignant neoplastic tumor of epithelial origin. There were no patients with germ cell ovarian tumors. Ovarian torsion occurred in $40(37.7 \%)$ patients in this study; all 40 patients presented with abdominal pain. The most common surgical approach and procedure were laparoscopy (67.0\%) and cystectomy $(60.4 \%)$, respectively. Salpingo-oophorectomy was performed in 8 patients (Table 3 ).

\section{DISCUSSION}

The aim of this study was to examine the treatment of adnexal disease during a recent 5-year period at our institution. In adolescents, adnexal masses can be associated with various symptoms (i.e., acute abdominal pain, large pelvic or abdominal mass, menstrual cycle alterations, and endocrine signs). In this study, abdominal pain was the most common initial symptom $(56.6 \%)$, which was similar to previous findings in literature (60\%-78\%) [10,11]. Abdominal pain may be subacute, acute, recurrent, abdominal, pelvic, and accompanied by gastrointestinal signs (i.e., nausea and vomiting). Tempelman et al. reported that abdominal pain and a palpable mass in $70 \%$ and $35.7 \%$ of patients with adnexal masses, respectively [12]. Malignant masses are larger and more palpable. In our study only one patient had malignant tumor and most of the other patients underwent emergency operations.

Pelvic ultrasonography should be the method of choice for establishing an initial diagnosis of adnexal masses. In this study, our diagnostic standard was ultrasonography and $84.9 \%$ of patients were diagnosed with adnexal masses by ultrasonography. In the literature, the first recommended diagnostic step is ultrasound [13]. Ultrasonography provides information regarding the nature of cysts, suspected adnexal torsion, or the presence of heterogeneous masses. The malignancy risk is very low for lesions that are unilocular, unilateral, have a smooth surface and thin wall, and no ascites [14]. Computed tomography and magnetic resonance imaging provide complementary information if more details regarding the masses are required or further questions persist. 
Physiologic and functional cysts, including follicular and corpus luteum cysts, are found commonly in adolescents. These cysts may be symptomatic with intracystic bleeding and cyst rupture, torsion, and enlargement. If an adolescent has been diagnosed with an ovarian cyst $>5 \mathrm{~cm}$ in diameter, she should be informed of the risks for cyst rupture or torsion and advised to seek care immediately if she becomes symptomatic. In this study, patients with non-neoplastic ovarian lesions presented with cyst rupture, intracystic bleeding, and torsion of the cyst with or without involvement of the ovary.

Acute pelvic inflammatory disease can commonly lead to severe abdominal pain in adolescents. For patients who are suspected of pelvic inflammatory disease, have a pelvic exam that is suboptimal, or are not responding to outpatient or inpatient antibiotic therapy after 24-48 hours, pelvic ultrasonographic imaging should be performed to determine the presence of pyosalpinx or tubo-ovarian abscesses. Two patients in our study had tuboovarian abscesses; both patients had undergone an appendectomy 20 and 30 days prior to the application, which was a risk factor for pelvic abscesses. The abscesses were successfully drained in the 2 patients. One of the patients had a ruptured hydatid cyst mimicking a pelvic abscess and another patient had pelvic tuberculosis mimicking malignancy. Surgeons should consider these rare conditions during all stages of the diagnosis and a multidisciplinary approach to treatment should be implemented. Overall, mature teratomas are the most common benign ovarian neoplasms in both the adult and pediatric populations; approximately $70 \%$ of benign ovarian neoplasms are mature teratomas in women $<30$ years [15]. Specifically, in the first 2 decades of life, $70 \%$ of all ovarian tumors are of germ cell origin and one-third of these tumors are malignant [16].

The surgical treatment for cystic teratomas is debated. In the past, laparotomy and salpingooophorectomy have been the most accepted treatment for the surgical treatment of teratomas. We suggest cystectomy to be the first-line treatment in the absence of elevated alfa-fetoprotein, a predominantly solid appearance ultrasonographically, or clear intraoperative evidence of malignancy (i.e., extracapsular extension, lymph node, or omental involvement) [17]. We have diagnosed 9 silent teratomas, which were not torsioned. Elective cystectomies were performed in these 9 patients.

Torsion of an ovarian mass is most frequent during the first 3 decades of life [18]. Traditionally, oophorectomies were used for treating ovarian tor- sion due to possible embolization after detorsion [19]. Thus far, thromboembolic events have not occurred in the gonadal veins of young girls during detorsion [20]. The surgical approach should be as conservative as possible in order to preserve future fertility; therefore, detorsion by laparoscopy or conventional surgery can be performed by puncturing a benign appearing cyst or cystectomy of a dermoid cyst [21-23]. In our experience, about $1 / 3$ of patients who required operations for ovarian pathology had ovarian torsion. Salpingectomy was performed for 2 cases of tubal torsion without ovarian tissue. When detorsion was performed for 32 patients, the ovary was well perfused and no complications (i.e., embolization and infection) occurred. The ovary was completely necrosed in 8 patients according to operation records. Therefore, salpingo-oophorectomy was preferred for those patients and all 8 patients were operated on before 2009. More recently, investigators have recommended detorsion and preservation of all ovaries (open or laparoscopic) even if the ovaries appear necrotic [24]. We have changed the management of patients with torsioned ovaries at our center by treatment recommendations and performing only detorsion as the routine surgical method. It is likely that oophoropexy causes adhesions and infertility by distortion of the ovaryfallopian tube, and therefore, we believe it should be avoided.

Any discussion of adnexal masses in adolescents would be incomplete without highlighting the importance of including ectopic pregnancies in the differential diagnosis. Adolescents with abdominal pain and vaginal bleeding should have a sensitive urine or serum pregnancy test performed and those with a positive test should undergo ultrasonographic evaluation. A patient with a positive pregnancy test who has a complex adnexal mass with an empty uterus is highly concerning. At our center, women who complain of abdominal pain and are of reproductive age are required to obtain a pregnancy test during the initial evaluation. In this study, 10 (9.4\%) patients underwent an operation for ruptured ectopic pregnancies ( $\mathrm{n}=2$ salpingostomies and 8 salpingectomies).

The decision to use laparotomy or laparoscopy in adolescent patients depends greatly on the laparoscopic skills of the treating surgeon. One of the aims of this study was to summarize our recent experience with treating adnexal disease using the laparoscopic approach. Mayer and colleagues previously suggested that laparoscopy (for treating ovarian cysts, including those with large diameters) 
is associated with satisfactory outcomes and few complications [25]. Laparoscopy offers a combination of diagnostic and therapeutic interventions with direct detorsion and possibility of oophorectomies in cases of complete ovarian necrosis $[19,26]$. In this study, $67.0 \%$ and $28.3 \%$ of operations were completed using laparoscopy and laparotomy, respectively. The procedure was converted to laparotomy in 5 patients secondary to adhesions. In one study, the rate of laparoscopic surgery $(74.4 \%)$ was comparable to the rate that was observed in our study which suggests the changing trends in adnexal surgery probably associated with technical advances [8]. Laparoscopy is a generally safe and beneficial alternative to laparotomy [27]. However, the laparoscopic approach has limitations if the patient is suspected of having a malignancy, has a large ovarian tumor.

The limitations of this study included characteristics of retrospective chart review, including unrecorded information, variance in the quality of information, and problems associated with data verification [28]. Laparoscopy can be performed in many adolescent patients and conservative, adnexal-sparing surgery should be encouraged for all patients when possible. However, as illustrated above, ovarian-preserving techniques should be a priority when surgery is performed for benign masses in order to optimize future fertility potential. Conversely, when an ovarian malignancy is identified, the complete excision of masses and accurate surgical staging are essential for improving patient outcome and guiding adjuvant therapy. A collaborative approach, incorporating both gynecologic and pediatric surgeons, is paramount for managing adolescent patients with adnexal masses.

Declaration of interest: The authors report no conflicts of interest.

\section{REFERENCES}

1. Logsdon VK. Common problems in pediatric and adolescent gynecologic surgery. Curr Opin Obstet Gynecol 2001;5:453-458.

2. Kirkham YA, Lacy JA, Kives S, Allen L. Characteristics and management of adnexal masses in a canadian pediatric and adolescent population. J Obstet Gynaecol Can 2011;33:935-943.

3. Cartault A, Caula-Legriel S, Baunin C, et al. Ovarian masses in adolescent girls. Endocr Dev 2012;22:194207

4. Spinelli C, Pucci V, Strambi S, et al. Treatment of Ovarian Lesions in Children and Adolescents: A Retro- spective Study of 130 Cases. Pediatr Hematol Oncol 2015;32:199-206.

5. Liu $\mathrm{H}$, Wang $X$, LuD, et al. Ovarian masses in children and adolescents in China: analysis of 203 cases. J Ovarian Res 2013;6:47.

6. Eskander Rn, Bristow RE, Saenz NC, Saenz CC. A retrospective review of the effect of surgeon specialty on the management of 190 benign and malignant pediatric and adolescent adnexal masses. J Pediatr Adolesc Gynecol 2011;24:282-285.

7. Batt RE. Adnexal masses in Korean children and adolescents. J Minim Invasive Gynecol 2010; 17: 665

8. Ryoo U, Lee DY, Bae DS, et al. Clinical characteristics of adnexal masses in Korean children and adolescents: retrospective analysis of 409 cases. J Minim Invasive Gynecol 2010;2:209-213.

9. Powell JK. Benign adnexal masses in the adolescents. Adolesc Med Clin 2004;15:535-547.

10. Cass DL, Hawkins E, Brandt ML, et al. Surgery for ovarian masses in infants, children, and adolescents: 102 consecutive patients treated in a 15 -year period. J Pediatr Surg 2001;36:693-699.

11. Piippo S, Mustaniemi L, Lenko $H$, et al. Surgery for ovarian masses during childhood and adolescence: a report of 79 cases. J Pediatr Adolesc Gynecol 1999;12:223-227.

12. Templeman C, Fallat ME, Blinchevsky A, Hertweck SP. Noninflammatory ovarian masses in girls and young women. Obstet Gynecol 2000;96:229-233.

13. Deligeoroglou E, Eleftheriades M, Shiadoes V, et al. Ovarian masses during adolescence: Clinical, ultrasonographic and pathological findings, serum tumor markers, and endocrinological profile. Gynecol Endocrinol 2004;19:1-8.

14. Knudsen UB, Tabor A, Mosgaard B, et al. Management of ovarian cysts. Acta Obstet Gynecol Scand 2004;83:1012-1021.

15. Templeman CL, Fallat ME, Lam AM, et al. Managing mature cystic teratomas of the ovary. Obstet Gynecol Surv 2000;55:738-745.

16. Berek JS, Natarajan S. Ovarian and fallopian tube cancer. In: Berek JS, editor. Berek \& Novak's Gynecology. Philadelphia, USA: Lippincott Williams \& Wilkins, 2007, p. 1457-1547.

17. Reddy J, Laufer MR. Advantage of conservative surgical management of large ovarian neoplasms in adolescents. Fertil Steril 2009;91:1941-1944.

18. Warner MA, Fleischer AC, Edell SL, et al. Uterine adnexal torsion: Sonographic findings. Radiology 1985;154:773-775.

19. Templeman C, Hertweck SP, Fallat ME. The clinical course of unresected ovarian torsion. J Pediatr Surg 2000;35:1385-1387.

20. Broach AN, Mansuria SM, Sanfilippo JS. Pediatric and adolescent gynecologic laparoscopy. Clin Obstet Gynecol 2009;52:380-389. 
21. Oltmann SC, Fischer A, Barber R, et al. Cannot exclude torsion - a 15-year review. J Pediatr Surg 2009;44:1212-1216.

22. Lo Lm, Chang SD, Horng SG, et al. Laparoscopy versus laparotomy for surgical intervention of ovarian torsion. J Obstet Gynaecol Res 2008;34:1020-1025.

23. Eckler K, Laufer MR, Perlman SE. Conservative management of bilateral asynchronous adnexal torsion with necrosis in a prepubescent girl. J Pediatr Surg 2000;35:1248-1251.

24. Mayer JP, Bettolli M, Kolberg-Schwerdt A, et al. Laparoscopic approach to ovarian mass in children and adolescents: already a standard in therapy. J Laparoendosc Adv Surg Tech 2009;19:111-115.
25. Mettler L, Semm K, Shive K. Endoscopic management of adnexal masses. J Soc Laparoendosc Surg 1997;1:103-112.

26. Jawad AJ, Al-Meshari A. Laparoscopy for ovarian pathology in infancy and childhood. Pediatr Surg Int 1998;14:62-65.

27. Mansuria SM, Sanfilippo JS. Laparoscopy in the pediatric and adolescent population. Obstet Gynecol Clin North Am 2004;31:469-483.

28. Worster A, Haines T. Advanced statistics: understanding medical record review (MRR) studies. Acad Emerg Med 2004;11:187-192. 